\title{
Introducing Good and Bad Virtues To Avoid Conflict In Javanese Society: A Study Case From Javanese Short Narrative For Children
}

\author{
Daru Winarti ${ }^{1}$, Aisyah Sabrina ${ }^{2}$ \\ Javanese Literature Program, Universitas Gadjah Mada ${ }^{1}$, Education Sciences Program, Université de \\ Paris (Université Paris-Descartes) ${ }^{2}$ \\ \{daru.w@ugm.ac.id\}
}

\begin{abstract}
Narratives, fairy tales, and other forms of storytelling have been long used as one of the means to educate children about good and bad values accepted in the society. Javanese society was no exception. However, the big question is how these values are presented and taught to children. This study aims to explore various virtues and values, good and bad, taught through narrative story telling for children in Java. The stories are collected from the weekly magazine Djaka Lodang, and only stories with human as the actors and with human interaction are chosen. Data collected are in the forms of lexicon, that have meaning as good or bad virtues, such as jujur 'honest', rukun 'harmonious', andhap asor 'humble', bekti 'devoted', ngajeni 'appreciate (others)', ugungan 'selfish', tukaran 'dispute (with other)' by regarding the sentence's context so the function of introducing these virtues could be seen clearly. These data are then analyzed using the approach of linguistic anthropology and moral development and education theory. The result reveals that Javanese society taught, not only the good virtues, but also the bad ones. A virtue can have positive meaning if there is another virtue as a comparison in its polarity, for example 'honest' is a good virtue, because its opposite 'lie' exists as the bad virtue. Introducing virtues of both polarities are done with the same goal, that is to avoid conflict with other people within the society. This actually corresponds with the main concept of socializing in Javanese society, achieving a harmonious society.
\end{abstract}

Keywords: storytelling for children, moral education, good-bad virtues, Javanese culture

\section{Introduction}

Moral values are introduced to children by their parents to prepare their children so they could have good life and relationship with other people in the society. These values were made as the guidance to comport themselves when they do their daily activities, notably the guidance that could induce physical and psychological comfort when socializing. For Javanese society, one of these comforts is to avoid conflict or dispute [1]. Javanese people need to thrive in these values, because the form of these values is highly complex. Not only adults who could have conflict, but children as well especially when they start to communicate with other. With children's stories, they can learn good and bad virtues, what should they do and avoid, because children's stories usually narrate figures with good or bad characters [2]. Since the language competency of children is still limited, these stories consider proper and unambiguous word or sentence so that the values could be understood more easily. 
Several previous studies usually analysed the moral education and development from different perspectives, from philosophy to psychology [3], and highlighted the aspect of morality and character. However, not many of it tried to explore these values through the cultural and societal perspectives, because there are always some morals and norms that are accepted in one culture, but unaccepted in other.

In his article published in 2012, Ahimsha-Putra explained further about good and bad morals in Javanese societies. Generally, values are abstract but it is not unclear, because these values should be easy to apply and utilize in daily lives [1]. Moral values should also mean in general, so it will not be dogmatic and can follow certain mutual agreement in the society. He also added that these moral values become an important symbolic set of daily life guidance as an individual and a part of the society. These statements are in accordance of what Aristotle had explained, that moral virtues produce generally several options of action, done in the name of personal and society welfare, in terms of moral or material [4].

Since these moral values are a symbolic set of daily life guidance for personal and societal use, thus these values can be divided into two characteristics, individual values and social values [1]. The individual values are a set of behaviour and characters that a person would have, while social values are the characters of each individual shown when they are socializing and communicating with others. To ease our reference, for the rest of this essay, individual values will be referred as virtues and social values will be kept the same.

Besides being distinguished from its characteristics (individual and social), values can also divide based on its meaning. Aristotle offered two types of values, that are virtue and vice. Virtue is a collection of many good characters or values, whereas vice is values that are not in accordance to the society's standards - and not just the opposite of positive characters. Carr [4] gave the example that the virtue of courageous can also be translated as an act in the grey area, such as headstrong recklessness because of two reasons. First of all, the act of recklessness could be blindly translated as the opposite of the vice of cowardice. Secondly, the action as the form of courageousness has a large span of interpretation that the society needs to determine, between the virtue and vice. This explanation is in accordance with Ahimsa-Putra's explanation about one of the social values accepted in Javanese culture, ngono ya ngono, ning aja ngono 'it's still fine if you act like that, but don't act to that extent'. This value is actually connected with the Javanese culture that prefers to avoid extremity (vice) and choose to be in the "middle", so what is called extremity has actually a boundary that one should not trespass [1].

This study will collect data from stories of a rubric entitled "Wacan Bocah" from the weekly Javanese magazine, Djaka Lodang, using the approach of linguistic anthropology. This approach has been actually developing for 100 years and is herited from two older disciplines, linguistic and anthropology, just like its name [5][6]. Therefore, this discipline tries to analyse language as a cultural source and cultural practice. This approach is surely different with other previous studies that, for example, explored the use of children stories as a form of moral education using pedagogy approach [7]; moral education using spiritual approach [8]; moral education and development perspective using philosophical approach[4][9]; or other studies regarding moral education for children using psychological perspective[3][10][11].

The method used and its result will be discussed on the next two chapters. The result will be divided into three sections that is characteristics of language form, virtues and social values, as well as principal characters in children's moral development of Javanese society. 


\section{Research Methods}

The analysis of values in this study is limited to the lexicons that are used to show the values or characters of the figures in "Wacan Bocah" rubric published in Djaka Lodang magazine. These values are analysed its characteristics of language form and then classified based on its meaning nature. The language form is analysed based on its morpheme, while the sentence is based on its function and situational relation [12], [13].

By analysing the sentence's type that contains the lexicon with good or bad meaning, the guidance of values in the society can be seen more clearly. The term used to describe virtue or vice is initially based on the understanding that virtue is in accordance to the society's mutual agreement, and vice is the contrary [1]. Lastly, these lexicons and sentences' types are finally analysed to see if they are the basic set of moral values needs to be taught to children.

\section{Results and Discussion}

\subsection{Characteristics of Language Form Different forms of lexicon}

Lexicons containing good and bad meaning in Javanese stories for children can be divided into two types of form, monomorphemic and polymorphemic. Monomorphemic, composed of only one free morpheme, i.e. cengeng 'cry baby' or jujur 'honest'. Whereas polymorphemic marked with the presence of affixation (-an), to describe a value adhered as a behaviour or character of the figure mentioned, i.e. nangisan 'like(s) to cry', kongkonan 'like(s) to give order', and also compound form, such as andhap asor or lembah manah 'humble'.

\section{Presence of lexicon in a sentence}

The majority of lexicon with good and bad meaning in rubric "Wacan Bocah" is explained in the form of statement, and the rest is in imperative sentence. The former is a sentence that is formally indicated with descended intonation at the end for speech or full stop for written sentence. The purpose is to inform, and the response expected would be an answer or a nod. From the data analysed, statements containing lexicon with bad and good meaning can be classified into several, while imperative sentence used only to prohibit something. The classification is further explained as below:

(1) Statements containing one lexicon with good or bad meaning, with the objective to label a certain character of a figure:

a. "Huh, senenge maca komik, cengeng". Panyengese Nugraha bareng ngerti apa kang diwaca adhine. "Cengeng ya ben ta", Panyendhune Yohana emoh kalah.

"'Huh, reading a comic, you are a cry baby". Nugraha sneered after figuring out what his sister is reading "So what if I'm a cry baby". Yohana's answer did not yield in' [14]

b. Sing jenenge kewan singa pancen kewan sing menangan dhewe

'Lions are the animals that want to win alone' [15]

c. "Ibu pancen pangerten tenan, kok."Nugraha jingkrak-jingkrak seneng.

'"Mom, you are very understanding." Nugraha jumped his heart out' [14] 
(2) Statements containing several lexicons referred to a figure's character with good or bad meaning, with the purpose to describe further a virtue that became the character of the figure:

a. .. Dewi Kuning paling seje dhewe, yaiku ngerti andhap asor, bekti marang wong tuwa, ngajeni marang liyan

'... Dewi Kuning is unique among others, she is humble, pays respect to her parents, and respect other people.[16]

b. Putri-putri sanga iku saya nakal, keset, senengane mung kongkonan marang emban lan juru taman.

'The nine daughters became more naughty, lazy, and likes to order around their helper or gardener.' [16]

(3) Statements containing contradictive lexicon with bad versus good meaning, with the objective of explain the virtues that one must have and the vices that one must avoid:

a. Kupu ireng ora ayu rupane ananging becik atine lan sregep nyambut gawe. Sewalike kupu kuning kang ayu rupane duweni sifat ala lan kesed banget

'Black butterflies are not pretty but they are kind hearted and diligent worker. On the contrary, yellow butterflies have beautiful appearence but they have bad characters and are very lazy'[17]

b. ..para putrane padha aleman, ugungan, lan nakal. Kejaba sing duwe watak kalem, meneng, bekti lan sregep sarta jujur amung sing ragil.

'... all the children are spoiled, selfish and naughty. Unless the youngest who is calm, quite, respect his/her parents and diligent as well as honest.' [16]

(4) Statements containing explanation of lexicon of bad or good character's figure, with the purpose of giving example of what one will gain with their good or bad character:

a. Dhasar bocahe gatekan tur tegen nggegulang kawasisane, wekasane Wulan bola bali kasil menangake sayembara

'Basically, the kid is attentive and determined when learning something, so Wulan can win many competitions' [18]

b. Dadi putri sanga kuwi padha ora duwe tatanan urip, seneng mbentak-mbentak marang emban............

'So the nine daughters, they have no rules, and like to yell at their helpers...' [16]

(5) Imperative statement, indicated by ordering intonation with the expected reaction is an action according to what has ordered, i.e.:

a. Nanging, kowe ora kena wadulan. Apa-apa mbokcritakke Bapak. Akibate kaya saiki, kita ora oleh lunga-lunga.

'But don't be a tattletale. You always tell everything to Father and now we cannot go' [14]

b. "Wis...wis. Ora tukaran ngono." Bu Prapto nengahi.

'Stop..stop. Don't fight like that." Bu Prapto interceded. [14]

\subsection{Virtues and social values}

Both virtues and social values are originated from the behaviour and character of an individual. However, the difference is that whether one would bring these behaviours and characters when socializing with other people in the society. Fundamentally, these virtues, good or bad, only the individual could gain the benefit or the loss. Yet, when one has the habit to do these virtues and make it as their character, then other people around them could also be 
impacted. With good virtues, other people will feel comfortable around them and feel the benefit of this virtues; whereas vices could make other people uncomfortable, and this individual would be less liked. Stories for children contained several good and bad values as a guidance for children to behave, individually or when they are in society.

\section{Bad individual values:}

a. Keset 'lazy' (2b). Laziness is originated from individual value, who usually do not like to take responsibility. Usually, it is initiated from the character ugungan 'likes to be praised or spoiled'. Javanese people consider that a lazy person will only bring impact to themself and make them nondependent. Furthermore, because of this laziness, this person prefers to order people around or kongkonan that would harm and burden other.

b. Nakal 'naughty, ill-behaved' (3b). The meaning of naughty actually covers a wide range of interpretation, but for Javanese society, a naughty child is usually one with exaggerated physical activities, likes to argue and overly expressive. The latter is actually derived from the habit of arguing too much with their parents, and this should not be done. If a child is allowed to do this, then this value would transform to a bigger social value, such as menangan 'egoist'.

c. Cengeng 'a cry baby' (5a). Yohana showed this bad value (5a), labelled by Nugraha when he teased her. This negative value is introduced to the story to teach that if this value is brought during socialization, it would make people feel in an uncomfortable situation. Moreover, the figure could also be labelled as someone co-dependent to others, unconfident, in despair and fragile

\section{Good individual values:}

a. Andhap asor 'humble' (2a). This character has the positive meaning for Javanese since they tend to dislike people who obtrude and boastful, and these two characters mean that the person is arrogant and cannot respect other. When one brings the attitude of andhap asor to the society, then one will be considered as someone bekti 'devoted' and ngajeni 'respect'.

b. Becik 'kind' (3a). The data (3a) shows the lexicon of becik 'kind' related to atine 'his/her heart', which means kindhearted. People with this attitude will always try to think positively, helpful, not envious, treat people equally, obedient, will try not to hurt people, so one will be able to avoid conflict.

c. Kalem, meneng also known as anteng 'calm, tranquil, at peace' (3b). These two attitudes will lead to the tranquillity on both physically and emotionally, and Javanese people prefer this attitude on someone. For them, people who can sit calmly, behave properly, and express their feelings accordingly is considered as someone who can control their emotion, so this type of people will be respected since they avoid conflict.

d. Sregep 'diligent' (3b). One who is diligent could easily gain place in the society because one will be asked to get involved in different events. Moreover, one could hone their competencies and establish good relationship with others [19].

e. Jujur 'honest (3b). By being honest, an individual can easily gain trust from other people, so other will feel comfortable around this person, and do not have any prejudice towards him/her [19].

f. Tegen 'studious' (4a). This is a positive attitude of someone who can also be considered as a hard-working person. In the future, people with this attitude can be successful and achieve good result as shown from data (4a). 


\section{Bad social values:}

a. Menangan 'egoist' (1b). This attitude is actually originated from naughtiness that is brought when socializing. Javanese people tend to dislike this attitude since it shows that the person is arrogant, thinks that he/she is better than everybody else, and even feeling superior, so other people are always wrong, and this person will never budge.

b. Kongkonan 'likes to order (people) around' ( $2 \mathrm{~b}$ ). This attitude is derived from laziness keset that is done so many times until it could burden other people. One with this attitude is considered co-dependent and tend to not care of other people's feelings.

c. Ora duwe tatanan 'to not have any rules' (4b). Tatanan refers to rules, meaning that one does not understand rules existing in the society, notably on how to behave properly; thus, explained from data (4b) that the figure likes to yell at the helper. This is actually another form of menangan.

d. Wadulan 'a tattletale' (5a). This attitude is almost the opposite of meneng and kalem 'calm, quite'. If one has this attitude, then one will not be preferred and tend to be avoided by other because it could humiliate other people and often times create a dispute between the tattled and the recipient of the tattle.

e. Tukaran 'to quarrel' (5b). This word is actually a verb but could also be seen as adjective by adding the word senang 'likes to' in front of. Someone who senang tukaran 'likes to quarrel' is usually the cause of a dispute. Javanese people do not like this attitude since it provokes a non-harmonious and non-conducive situation in the society.

\section{Good social values:}

a. Pangerten 'understanding' (1c). People with this attitude is usually able to tell and understand the purpose and willingness of others, so this person has the capacity to emphasize and tolerant to other people. Having this attitude will make on accept the diversity of each person, and practice on their sincerity. This will surely avoid conflict.

b. Bekti 'devoted' (2a). This is a form of good attitude based on obedience and respect to people, also devout to God. One of the examples of respecting older people or parents is to obey their instruction, to care and love them, as well as pray for them. Javanese people believe that devout will make other people happy and one can also feel the reciprocal happiness [19].

c. Ngajeni 'to respect' (2a). The example of ngajeni is one being able to apologize when making mistake, to express gratitude, to keep promise, and to not cut another people's talk. One with this attitude is someone who can control their emotion and not feel superior towards other. On the contrary, one without this attitude is usually someone who expects too much on another people's kindness dan could not respect themselves.

d. Gatekan 'care (to) others' (4a). People with this attitude is usually helpful towards other, and tend to spend some time to think of how other people will react towards his action, so other will feel comfortable around him/her.

\subsection{Characteristics of moral development in children}

Berkowitz and Grych [3] explained ten principal characters that are important to be introduced in moral education to support children's moral development. The ten characters are also indicated, directly or indirectly through the lexicons in rubric "Wacan Bocah" and also through the form of sentences.

a. Self-control. A child is expected to be able to control their emotion and desires. This part is shown from the words kalem and meneng (3b). In principle, when emotion and internal 
struggle appeared in someone can be controlled properly, then it will also show in his action and attitude.

b. Self-esteem. This attitude is developed along with less frequency of crying of a child, so they become more independent and have better self-esteem.

c. Honesty. This is one of the most important attitudes of a child to keep their pure heart and gain trust from others in the society.

d. Empathy. The attitude is similar to the meaning from andhap asor where a child can be sensitive to the emotion and desire of people around them.

e. Social orientation. Similar to empathy, the attitude of andhap asor also covers the aspect of social orientation, where one could hide their own ego to defend something. This will affect to the development of pangerten 'understanding' attitude when socializing in the society.

f. Altruism. Having good attitude and avoiding bad attitude as mentioned in 3.2.3 and 3.2.4 is not only on the objective of making other people happy and comfort with a person, but also to train on being considerate about others' needs. Javanese people believe that if they have good social values, such as pangerten, bekti, ngajeni and gatekan; it is also possible that they will be treated the same by others. When socializing, it is important to keep a reciprocal dynamic between individuals.

g. Conscience. A child has a good conscience and realize when they done something unaccordingly. This attitude could be honed from good social control from various parties done consistently (data 5a and 5b).

h. Moral reasoning. This main characteristic become one of Plato's explanation that a child will be able to recognize, differentiate, and behave accordingly to the social values. Therefore, moral and its meaning must be elaborated through a thorough explanation with similar meaning (data $2 \mathrm{a}$ and $2 \mathrm{~b}$ ), with contestation (data $3 \mathrm{a}$ and $3 \mathrm{~b}$ ), or with given example (data $4 \mathrm{a}$ and $4 \mathrm{~b}$ ).

i. Social skills. This attitude will be appeared when one is humble andhap asor, becik (atine), kalem, and meneng. With this attitude, one can behave calmly, able to not attract attention to them only, and could focus on how one can place themself in the society where the dynamic can change at any time and pay attention on other people's suggestion for their well-being.

j. Compliance. A child is expected to be able to comply to different rules existed. This can be achieved with explanation of moral (data 2a, 2b, 3a, 3b, 4a, and 4b) and social control kontrol sosial (5a and 5b).

\section{Conclusion}

The above explained and elaborated shortly about several morals accepted in Javanese society that are initially introduced since early years of children. These values are actually the principal characters that serve as the guidance to moral development for children. These values are presented in different lexicons and forms of speech, usually done by adult to their children or by older people to the younger.

Furthermore, when discussing about moral, not only morals with good meaning that are introduced to children, but also morals with bad meaning. The objective is not to teach bad morals to children, but rather to give a more thorough explanation of moral limitations existed in society's norms. Thus, the morals with good meaning can be understood more easily by 
children. These moral with bad meanings can also serve as reflexion and self-introspection materials for children so they could avoid these vices.

Several lexicons of individual values are juxtaposed with lexicons of social values. This shows several interpretations. First, the individual attitude is actually owned by only the individual attached but could relate to other people notably if this attitude is brought when socializing with other people in the society. Second, individual and social values tend to project each other. Several virtues, such as andhap asor or kalem, shows that if an individual is able to respect other people, then they can also respect themselves.

By respecting oneself, then one is able to respect, at least, the existence of other people around them. Thus, it will help to emerge a harmonious and peacefulness in society, while avoiding conflict between individuals. This is actually the main objective of early moral education in Javanese society, that is conflict avoidance that could provoke dispute and feud.

\section{References}

[1] H. S. Ahimsa-Putra, "Baik dan Buruk dalam Budaya Jawa, Sketsa Tafsir Nilai-nilai Budaya Jawa," Patrawidya, vol. 13, no. 3, pp. 383-410, 2012.

[2] B. Nurgiyantoro, Sastra Anak: Pengantar Pemahaman Dunia Anak. Yogyakarta: Gadjah Mada University Press, 2013.

[3] M. W. Berkowitz and J. H. Grych, "Early Character Development and Education," Early Educ. Dev., vol. 11, no. 1, pp. 55-72, 2000, doi: 10.1207/s15566935eed1101_3.

[4] D. Carr, Educating the Virtues: An Essay on the Philosophical Psychology of Moral Development and Education. London: Routledge, 1991.

[5] A. Duranti, Linguistic Anthropology. New York: Cambridge University Press, 1997.

[6] S. Wortham, "Linguistic Anthropology of Education," Annu. Rev. Anthropol., vol. 37, pp. 37-51, 2008, doi: 10.1146/annurev.anthro.36.081406.094401.

[7] H. Rahim and M. D. H. Rahiem, "The Use of Stories as Moral Education for Young Children," Int. J. Soc. Sci. Humanit., vol. 2, no. 6, pp. 454-458, 2013, doi: 10.7763/ijssh.2012.v2.145.

[8] T. Eaude, Children's Spiritual, moral, social and cultural development: Primary and Early Years. 2008.

[9] D. Carr and J. Steutel, Virtue ethics and moral education. 2005.

[10] J. Murray, "Value/s in early childhood education,” Int. J. Early Years Educ., vol. 26, no. 3, pp. 215 219, 2018, doi: 10.1080/09669760.2018.1490849.

[11] D. M. Shumaker and R. V Heckel, Kids of Character: A Guide to Promoting Moral Development. 2007.

[12] M. Ramlan, Ilmu Bahasa Indonesia: Sintaksis. Yogyakarta: CV. Karyono, 2005.

[13] R. K. Rahadi, Pragmatik Kesantunan Imperatif Bahasa Indonesia. Jakarta: Erlangga, 2005.

[14] A. BN Pangastuti, “Wewadi Omah Angker,” Djaka Lodang, Yogyakarta, pp. 40-41, 1995.

[15] P. Gun W, “Sing Sombong Bakal Kejeglong,” Djaka Lodang, Yogyakarta, p. 6, 2020.

[16] S. Kusuma, "Kembang Kemuning,” Djaka Lodang, Yogyakarta, p. 22, 2020.

[17] T. Concat, "Kupu-kupu Ireng lan Kupu-kupu Kuning,” Djaka Lodang, Yogyakarta, p. 22, 2020.

[18] S. A. Harjono, "Putri Sejati," Djaka Lodang, Yogyakarta, p. 22, 2018.

[19] D. Winarti, "Tembang Dolanan dalam Masyarakat Jawa (Kajian Linguistik Antropologis)," Universitas Gadjah Mada, 2016. 